\title{
Effective production of lactic acid by a newly isolated alkaliphilic Psychrobacter maritimus BoMAir 5 strain
}

\begin{abstract}
The contamination risk during lactic acid production is one of the challenges to be overcome for effective fermentation because most reported lactic acid bacteria are neutrophilic strains. Therefore, in this study, a newly isolated alkaliphilic lactic acid bacterium was selected among several isolates obtained from natural sources. This isolate was identified as Psychrobacter maritimus BoMAir 5 using morphological, biochemical fermentation tests and $16 \mathrm{~S}$ rRNA gene sequencing. The strain exhibited homo lactic acid fermentation from glucose at $\mathrm{pH}$ 9.0. It also showed broad sugars utilization especially those derived from lignocellulosic biomasses. Cultural and nutritional conditions were optimized for efficient lactic acid fermentation. Lactic acid concentration of $140.8 \mathrm{~g} / 1$ with yield of $0.94 \mathrm{~g} / \mathrm{g}$ of consumed glucose was obtained using multi-pulse fed batch fermentation system with $\mathrm{pH}$ controlled at 9.0 and $40^{\circ} \mathrm{C}$. For biotechnological application, Psychrobacter maritimus BoMAir 5 represents a potential strain for high lactic acid production under conditions that limit the contamination risk of fermentation.
\end{abstract}

Keywords: lactic acid production, alkaliphilic bacteria, fed-batch fermentation, psychrobacter maritimus
Volume I Issue 3 - 2016

\author{
Abdel-Rahman MA, Hassan SED, Azab MS, \\ Gaber MA \\ Department of Botany and Microbiology,Al-Azhar University, \\ Egypt
}

\author{
Correspondence: Saad El-Din Hassan, Botany and \\ Microbiology Department, Faculty of Science, Al-Azhar \\ University, Nasr City, Cairo-I I 884, Egypt, \\ Email Saad.el-din.hassan@umontreal.ca
}

Received: December 08, 2016 | Published: December 28, 2016

\section{Introduction}

Lactic acid (LA) is very important chemical that is used for food, pharmaceutical, textile, cosmetic and chemical industries. ${ }^{1,2,3}$ LA is also an important building block in solvents and substances of biological activities ${ }^{4}$ and in the production of poly lactic acid, which is a biodegradable and biocompatible plastic material. Interestingly, pure L or D-LA can be only produced by microbial fermentation whereas chemical synthesis of LA produces a racemic mixture. ${ }^{5}$ Microbial fermentation of LA can be mainly achieved by some types of microorganisms e.g. fungi and LA producing bacteria. ${ }^{6}$ On the other hand, most of these organisms preferred the neutral or slightly acidic $\mathrm{pH}$ range of 5.5-6.5 that might increase the risk of contamination. Fermentation at alkaline conditions is one of the potential solutions to overcome this challenge, as these conditions are not favourable for most contaminant strains. ${ }^{8}$

Alkaliphilic microorganisms are defined as those preferred $\mathrm{pH} 9.0$ or above for their optimal growth. ${ }^{9}$ These microorganisms can tolerate high level of salts especially mono valent ions as sodium ions that is an advantageous character. ${ }^{7}$ Their tolerance to these levels of salt and high value of $\mathrm{pH}$ could also minimize the risk of contamination. ${ }^{10}$ Alkaliphilic strains can also considered good producers for organic acids. ${ }^{11}$ Very few alkaliphilic strains have been reported for LA production from glucose such as Halolactibacillus halophilus that produced $65.8 \mathrm{~g} / \mathrm{l} \mathrm{L}-\mathrm{LA}$ in batch fermentation at $\mathrm{pH} 9.0$ with a low yield of $0.76 \mathrm{~g} / \mathrm{g},{ }^{10}$ Exiguobacterium 8-11-1 strain produced $125 \mathrm{~g} / \mathrm{l}$ of L-LA with a yield of $0.98 \mathrm{~g} / \mathrm{g}$ in fed batch fermentation at $\mathrm{pH} 8.5,{ }^{12}$ Enterococcus casseliflavus $79 \mathrm{w} 3$ that produced $103 \mathrm{~g} / 1$ of L-LA with a low yield of $0.80 \mathrm{~g} / \mathrm{g}$ at $\mathrm{pH} 8.0 \mathrm{in}$ batch fermentation ${ }^{13}$ and genetically modified Bacillus N16-5 that produced $143.9 \mathrm{~g} / 1$ of D-LA with a yield of $96.1 \mathrm{~g} / \mathrm{g}$ of glucose consumed in fed batch fermentation. ${ }^{14}$ These studies either reported a low concentration of LA with low yield or performed at slightly alkaline conditions that increase the risk of contamination, in addition to the expected instability of genetically modified organisms. Therefore, this study aims to isolate wild-type alkaliphilic LAB from natural sources; in addition, screening and characterizing the most potent LA producer strain was evaluated. Moreover, optimization of the fermentation conditions for obtaining high LA production titre using different fermentation modes were determined.

\section{Materials and methods}

\section{Isolation and screening of alkaliphilic LAB}

Forty soil and water samples collected from Alex, Matrouh and Wady El-Natron and thirty-five samples of different dairy products were collected from different locations in Egypt. One gram of each solid sample or one $\mathrm{ml}$ of each liquid were suspended in $100 \mathrm{ml}$ of $0.85 \% \mathrm{NaCl}$, then $5 \mathrm{ml}$ of the suspensions were added to $100 \mathrm{ml}-$ Erlenmeyer flask containing $50 \mathrm{ml}$ of De Man, Rogosa and Sharpe (MRS) media that contained (g/l) glucose, 20; yeast extract, 5; poly peptone, 10; beef extract, $10 ; \mathrm{K}_{2} \mathrm{HPO}_{4}, 2 ; \mathrm{MgSO}_{4}, 0.1 ; \mathrm{MnSO}_{4}$, 0.05 ; sodium acetate, 5 ; ammonium citrate, 2 and tween $80,1 \mathrm{ml}$ and incubated at $37^{\circ} \mathrm{C}$ for $30 \mathrm{~h}$. Bacterial colonies were purified until obtaining single colonies. The obtained strains were grown on MRS agar medium supplemented with $0.4 \mathrm{~g} / 1$ bromocresol green to indicate acid production. All bacterial isolates were maintained in MRS media contained $15 \%$ glycerol at $-80^{\circ} \mathrm{C}$ for storage. The obtained isolates were subjected to primary screening methods for selection the bacterial isolates by growing in MRS broth medium at $37^{\circ} \mathrm{C}$ for $30 \mathrm{~h}$. The selected isolates were then subjected to secondary screening in order to test the ability of bacteria to grow on high concentrations of glucose $(50$ and $100 \mathrm{~g} / \mathrm{l})$ and sodium acetate $(10$ and $20 \mathrm{~g} / \mathrm{l})$.

\section{Characterization and identification of the most po- tent bacterial strain}

Morphological (cell shape, arrangement, colony shape and colour), biochemical and physiological characteristics ${ }^{15,16}$ were determined 
using API 50CHL test kit (bioMerieux, Marcy l' 'Etoile, 'France). For the 16SrRNA analysis, genomic DNA was extracted according to modified method. ${ }^{17}$ An aliquot of DNA $(1 \mu \mathrm{l})$ was added to a polymerase chain reaction (PCR) reagent mix. Where, 16S rRNA was amplified in PCR using the genomic DNA as template and bacterial universal primers, 27f (5-GAGTTTGATCACTGGCTCAG-3) and $1492 \mathrm{r}$ (5-TACGGCTACCTTGTTACGACTT-3) ${ }^{18}$ to amplify an approximately $1.5 \mathrm{~Kb}$ of $16 \mathrm{~S}$ rRNA gene. The PCR mixture $(50 \mu \mathrm{l})$ contained $1 \times \mathrm{PCR}$ buffer, $0.5 \mathrm{~mm} \mathrm{MgCl}_{2}, 2.5 \mathrm{U}$ Taq DNA polymerase (QIAGEN), $0.25 \mathrm{~mm} \mathrm{dNTP}, 0.5 \mu \mathrm{M}$ of each primer and $1 \mu \mathrm{l}$ of extracted bacterial genomic DNA. The PCR was performed in a DNA Engine Thermal Cycler (PTC-200, BIO-RAD, USA) with a hot starting performed at $94^{\circ} \mathrm{C}$ for $3 \mathrm{~min}$, followed by 30 cycles of $94^{\circ} \mathrm{C}$ for $0.5 \mathrm{~min}, 55^{\circ} \mathrm{C}$ for $0.5 \mathrm{~min}$ and $72^{\circ} \mathrm{C}$ for $1 \mathrm{~min}$, followed by a final extension performed at $72^{\circ} \mathrm{C}$ for $10 \mathrm{~min}$. The PCR products were commercially sequenced by Sigma Company using ABI 3730x DNA sequencer with the two primers. The 16SrRNA sequence was compared against the GenBank database using the NCBI BLAST program. Sequences were then compared with 16SrRNA sequences in the GenBank database using BLASTN. Multiple sequence alignment was done using ClustalX 1.8 software package and a phylogenetic tree was constructed by the neighbour joining method using MEGA (Version 6.1) software. The confidence level of each branch $(1,000$ repeats) was tested by bootstrap analysis.

\section{Effect of different $\mathrm{pH}$ on LA fermentation}

To study the effects of $\mathrm{pH}$ on LA production, batch fermentations were conducted at $37^{\circ} \mathrm{C}$ in the $100 \mathrm{ml}$-Erlenmeyer flasks containing $50 \mathrm{ml}$ of MRS medium containing $20 \mathrm{~g} / 1$ glucose. The $\mathrm{pH}$ was adjusted at 5.0, 6.0, 7.0, 8.0, 8.5, 9.0, 10.0 and 11.0 where the control of $\mathrm{pH}$ was conducted using $10 \mathrm{M} \mathrm{NaOH}$. Samples ( $3 \mathrm{ml}$ of fermentation media) were taken every $3 \mathrm{~h}$ of fermentation in the first $12 \mathrm{~h}$ and every $6 \mathrm{~h}$ after that until the end of fermentation period to measure cell growth $\left(\mathrm{OD}_{600}\right)$, glucose consumption and LA concentration.

\section{Effect of nitrogen sources on LA fermentation}

In order to determine the best concentration of nitrogen sources for LA production, different concentrations of YE $(0-10 \mathrm{~g} / \mathrm{l})$, peptone $(0-25 \mathrm{~g} / 1)$ and beef extract $(0-25 \mathrm{~g} / \mathrm{l})$ were performed individually in $100 \mathrm{ml}$-Erlenmeyer flasks containing $50 \mathrm{ml}$ of the media described above at $37^{\circ} \mathrm{C}$ for $30 \mathrm{~h}$. To study the optimal nitrogen source for bacterial growth and LA fermentation parameters by BoMAir 5, nitrogen sources of the MRS media were replaced by equivalent amounts of different organic and inorganic nitrogen sources. Soybean, urea, ammonium nitrate, ammonium sulphate, ammonium oxalate, ammonium chloride and ammonium ferric citrate were used individually as nitrogen sources in the $100 \mathrm{ml}$-Erlenmeyer flasks at the previous optimized conditions

\section{Optimization of temperature}

The optimal temperature for LA fermentation by BoMAir 5 strain was tested in $100 \mathrm{ml}$ Erlenmeyer flasks containing $50 \mathrm{ml}$ medium as described above. An initial $\mathrm{pH}$ was adjusted to 9.0 by adding sterilized $10 \mathrm{M} \mathrm{NaOH}$. Fermentations were conducted statically at $25,30,37$, $40,45,50,55$ and $60^{\circ} \mathrm{C}$. Intermittent samples were taken along the fermentation period to determine the optimal temperature which used in the next step of optimization.

\section{Effect of different carbon sources on LA fermentation}

Different carbon sources (glucose, fructose, lactose, sucrose, raffinose, maltose, starch and cellulose) were also used to determine the optimal carbon source for LA fermentation. This experiment was achieved in MRS medium supplemented with different carbon sources at an initial concentration of $20 \mathrm{~g} / 1$ at $40^{\circ} \mathrm{C}$ for $30 \mathrm{~h}$ and previous optimized conditions were considered. Moreover, different glucose concentrations of 20,40,60,80,100 and $150 \mathrm{~g} / 1$ were used to determine the glucose tolerance of strain BoMAir 5 at the previous optimized conditions. This experiment was performed under $\mathrm{pH}$ control at 9.0 using $10 \mathrm{M} \mathrm{NaOH}$.

\section{Fed batch fermentation}

Fed-batch fermentation was performed in a 1.0-1 bioreactor with a working volume of $300 \mathrm{ml}$ of optimized medium. The pre-culture was as that used in the batch experiments. Fed-batch fermentation was initiated by the adding of $10 \%(\mathrm{v} / \mathrm{v})$ inoculum. Temperature maintained at $40^{\circ} \mathrm{C}$ and the $\mathrm{pH}$ was controlled at 9.0 by $\mathrm{NaOH}(10 \mathrm{M})$. Samples were taken every $3 \mathrm{~h}$ at the first $108 \mathrm{~h}$ and every $6 \mathrm{~h}$ after that and the culture growth $\left(\mathrm{OD}_{600}\right)$, glucose concentrations and LA concentrations were determined. Feeding strategies were used for improving the fermentation efficiency. When the residual glucose concentration reached to $10 \mathrm{~g} / 1$, glucose $(30 \mathrm{~g} / 1)$ and $\mathrm{YE}(1.0 \mathrm{~g} / \mathrm{l})$ were added to the bioreactor, these supplementations were repeated four times.

\section{Analytical methods}

The culture growth was estimated based on $\mathrm{OD}_{600}$ measurements using a visible spectrophotometer. After $\mathrm{OD}_{600}$ measurements, the cultures were centrifuged at $6,000 \mathrm{rpm}$ for $10 \mathrm{~min}$ and the supernatants were subjected for glucose and LA determination. Residual glucose in the broth was estimated by using 3,5-dinitrosalicylic acid reagent (DNS method). ${ }^{17}$ LA was measured by Barker and Summerson method. ${ }^{19}$ Firstly, LA was converted to acetaldehyde through oxidation with concentrated sulphuric acid. Acetaldehyde after that was coupled with p-hydroxy diphenyl in the presence of cupric ions forming a purple compound. The absorbance of this purple compound was measured by using spectrophotometer at $570 \mathrm{~nm}$. All experiments were conducted at triplicates, data were statistically analyzed by SPSS v17, analysis of variance (ANOVA) test was used for multiple sample comparison, when normality and homogeneity of variance were satisfied, followed by multiple comparison Tukey test.

\section{Results and discussion}

\section{Isolation and screening of lactic acid producing bac- teria}

In the current study, 170 alkaliphilic strains were isolated from different sources, where preliminary screening resulted in the selection of 34 isolates that detected to produce LA concentration more than $4.0 \mathrm{~g} / 1$ with high yield $(>0.80 \mathrm{~g} / \mathrm{g})$ of glucose consumed). Secondary screening tests were performed to select the most potent bacterial isolates based on their tolerance to high glucose concentrations (50 and $100 \mathrm{~g} / \mathrm{l})$ and high sodium acetate concentrations (10 and 20g/1). Bacterial strain of BoMAir 5 was selected as the most potent among all rod shape and catalase positive bacterial isolates. This isolate appears to be homo fermentative LA bacterium because it can produce $9.6 \mathrm{~g} / 1$ of LA from $11.0 \mathrm{~g} / 1$ glucose with a yield $0.87 \mathrm{~g} / \mathrm{g}$ of glucose consumed. 


\section{Characterization and identification of the most po- tent isolate}

Strain BoMAir 5 was identified based on morphological, physiological characters as shown in (Table 1). BoMAir 5 strain showed circular and convex colonies with white colour on agar plates. Cells are Gram negative, short rods shape, catalase positive. This strain can produce acid from several carbohydrates as shown in (Table 1). BoMAir 5 strain can grow at wide $\mathrm{pH}$ range of 7.0-10.0; however, the optimal $\mathrm{pH}$ for the maximum growth was 9.0 , but it cannot grow at $\mathrm{pH}$ 5.0, 6.0 and 11.0. This strain cannot hydrolyse urea, pectin or cellulose, gelatine and citrate. Most properties are consistent with previous reported Psychrobacter strains. ${ }^{20,21}$ In contrast, strain BoMAir 5 differ from all other Psychrobacter strains in that it can utilize fructose as a sole carbon source producing LA homo fermentatively. Strain
BoMAir 5 cannot tolerate higher concentration of $\mathrm{NaCl}$ than $7.5 \%$. The acid production was compared to those of other Psychrobacter references strains such as Psychrobacter arenosus KMM $3659^{\mathrm{T} 20}$ and Psychrobacter piscatorii T-3-2 ${ }^{\mathrm{T}}{ }^{21}$ Surprisingly, BoMAir 5 can tolerate higher temperature until $55^{\circ} \mathrm{C}$ with optimum temperature at $40^{\circ} \mathrm{C}$ that differ from other reported Psychrobacter strains that cannot grow above $37^{\circ} \mathrm{C}$. In addition, Strain BoMAir 5 cannot haemolyse human blood agar plates indicating the bio-safety of this strain. Molecular identification based on 16srRNA gene sequence analysis of BoMAir 5 strain showed the identity of $99 \%$ to Psychrobacter maritimus strain pi2-20 (accession number NR 027225). The phylogenetic tree showed that the topology of BoMAir 5 strain to Gamma proteo-bacteria (Figure 1). From these analyses, strain BoMAir 5 was identified as Psychrobacter maritimus BoMAir 5.

Table I Morphological and biochemical characterization of BoMAir 5 strain

\begin{tabular}{|c|c|c|c|c|c|}
\hline \multicolumn{2}{|c|}{$\begin{array}{l}\text { Morphological and biochemical } \\
\text { characteristics }\end{array}$} & \multicolumn{4}{|l|}{ Sugar fermentation } \\
\hline Character & & Sugar & $\begin{array}{l}\text { Recorded } \\
\text { results }\end{array}$ & Sugar & $\begin{array}{l}\text { Recorded } \\
\text { results }\end{array}$ \\
\hline Cell shape & Short rods & Arbutin & + & Starch & + \\
\hline Colony Color & White & Glycerol & + & Glycogen & \\
\hline Colony shape & Convex & Erythritol & - & Xylitol & - \\
\hline Gram stain & - & d-Arabinose & - & Gentobiose & - \\
\hline Catalase activity & + & I-Arabinose & - & d-Turnose & - \\
\hline Fermentation type & Homo & Ribose & + & d-Lyxose & - \\
\hline Growth temperature & & d-Xylose & - & $d$-Tagatose & - \\
\hline $25^{\circ} \mathrm{C}-55^{\circ} \mathrm{C}$ & + & I-Xylose & - & d-Fructose & - \\
\hline $60^{\circ} \mathrm{C}$ & - & Adonytol & - & I-Fructose & - \\
\hline Growth pH & & $\beta$-Methyle-d-xyloside & - & d-Arabitol & - \\
\hline $5.0-6.0$ & - & Galactose & - & I-Arabitol & - \\
\hline $7.0-10.0$ & + & Glucose & + & Gluconate & + \\
\hline 11 & - & Fructose & + & $\begin{array}{l}\text { 2-Keto- } \\
\text { Gluconate }\end{array}$ & - \\
\hline Tolerance to $\mathrm{NaCl} \%$ & & Mannose & - & $\begin{array}{l}\text { 5-Keto- } \\
\text { Gluconate }\end{array}$ & - \\
\hline $1.5-5.0$ & + & Sorbose & - & Esculin & + \\
\hline $7.5-10.0$ & - & Rhamnose & - & Salicin & + \\
\hline Hydrolysis of & & Dulcitol & - & Cellobiose & + \\
\hline Urea & - & Inositol & - & Maltose & + \\
\hline Citrate & - & Mannitol & - & Lactose & - \\
\hline Pectin & - & Sorbitol & - & Melibiose & - \\
\hline Starch & + & $\alpha$-Methyle-d-Mannoside & - & Sucrose & - \\
\hline Cellulose & - & $\alpha$-Methyl d-Glucoside & - & Trehalose & + \\
\hline Gelatin & - & $\begin{array}{l}\text { N-Acetyle- } \\
\text { Glucosamine }\end{array}$ & + & Inulin & - \\
\hline \multirow[t]{2}{*}{ Blood } & - & Amygdalin & + & Melezitose & - \\
\hline & & & & Raffinose & - \\
\hline
\end{tabular}

\footnotetext{
+: Positive reaction, -: Negative reaction.
} 


\section{Effect of pH on lactic acid fermentation}

The initial $\mathrm{pH}$ of the fermentation medium considered a critical factor for microbial growth and the selection of LA producing bacteria based on initial $\mathrm{pH}$ considers useful parameter in biotechnology. ${ }^{22}$ In the current study, batch fermentations were conducted at various $\mathrm{pH}$ values of 5.0, 6.0, 7.0, 8.0, 8.5, 9.0, 10.0 and 11.0 to determine the best $\mathrm{pH}$ value for LA fermentation by strain BoMAir 5. The optimum results for $\mathrm{OD}_{600}$ of fermentation broth, LA concentration, LA yield, LA productivity and maximum LA productivity were obtained at $\mathrm{pH}$ 9.0 , with values of $0.76,10.4,0.90 \mathrm{~g} / \mathrm{g}$ of glucose consumed, $0.35 \mathrm{~g} / \mathrm{l} / \mathrm{h}$ and $1.6 \mathrm{~g} / \mathrm{l} / \mathrm{h}$, respectively (Table 2). On the other hand, lower results recorded at other $\mathrm{pH}$ values while the growth was completely inhibited at $\mathrm{pH}$ values of 5.0, 6.0 and 11.0; so, no LA production was detected at these $\mathrm{pH}$ values (Table 2). Therefore, the $\mathrm{pH} 9.0$ was selected for further investigations. From these results, Psychrobacter maritimus BoMAir 5 appeared to be more advantageous as LA producer because it was preferred alkaliphilic conditions than the common LAB, which preferred neutral to acidic conditions. ${ }^{23,24}$ Alkaliphilic strains tolerance to high levels of salts is helpful to reduce the contamination risk and decrease the amount of required neutralizing agents. ${ }^{10}$

\section{Optimization of fermentation medium}

LA bacteria are fastidious organisms, which need complex nutrients as amino acids and vitamins for cell growth. ${ }^{25}$ Therefore, it is necessary to determine the optimal medial composition for the maximum LA production under limited nutritional conditions. Different concentrations of yeast extract $(0-10 \mathrm{~g} / \mathrm{l})$, peptone $(0-25 \mathrm{~g} / \mathrm{l})$ and beef extract $(0-25 \mathrm{~g} / \mathrm{l})$ were used individually as nitrogen sources in batch fermentations with initial $\mathrm{pH}$ 9.0. Cell growth, glucose consumption, LA concentration and LA productivity were gradually increased with increasing nitrogen sources concentration up to the optimal values. The optimal concentration of YE was $7.5 \mathrm{~g} / 1$ which gave values of $0.92,11.7 \mathrm{~g} / 1,10.6 \mathrm{~g} / \mathrm{l}$ and $0.35 \mathrm{~g} / \mathrm{l} / \mathrm{h}$, respectively. Also, the best concentration of peptone for all fermentation parameters by BoMAir 5 was $20 \mathrm{~g} / 1$ with values of $0.98,12.0 \mathrm{~g} / 1,10.8 \mathrm{~g} / 1$ and $0.36 \mathrm{~g} / \mathrm{l} / \mathrm{h}$, respectively. On the other hand, $10 \mathrm{~g} / \mathrm{l}$ beef extract appear to be the optimal concentration for LA fermentation by BoMAir 5 strain, where the recorded results were $0.82,12.0 \mathrm{~g} / 1,10.9 \mathrm{~g} / 1$ and $0.36 \mathrm{~g} / \mathrm{l} / \mathrm{h}$, respectively (Table 3 ). The highest LA concentration was reached to $10.9 \mathrm{~g} / 1$ after the optimization of nitrogen sources in the media.

Table 2 Effect of different $\mathrm{pH}$ values on the bacterial growth, glucose consumption, LA concentration, LA yield, LA productivity and maximum LA productivity from glucose by Psychrobacter maritimus BoMAir 5

\begin{tabular}{|c|c|c|c|c|c|c|}
\hline $\mathrm{pH}$ value & $O D_{600} n^{\prime}$ & $\begin{array}{l}\text { Consumed glucose } \\
(\mathrm{g} / \mathrm{l})\end{array}$ & LA conc. $(\mathrm{g} / \mathrm{l})^{2}$ & YLA $(g / g)^{3}$ & $\operatorname{PLA}(g / / / h)^{4}$ & $\operatorname{Max} . \operatorname{PLA}(g / / / h)^{5}$ \\
\hline 5 & $0.153 \pm 0.0 \mathrm{I}^{\mathrm{d}}$ & $0.0 \pm 0.0^{d}$ & $0.0 \pm 0.0^{d}$ & $0.0^{\mathrm{d}}$ & $0.00^{d}$ & $0.00^{d}$ \\
\hline 6 & $0.343 \pm 0.0 I^{c}$ & $0.0 \pm 0.0^{d}$ & $0.0 \pm 0.0^{d}$ & $0.0^{\mathrm{d}}$ & $0.00^{d}$ & $0.00^{d}$ \\
\hline 7 & $0.540 \pm 0.0 \mathrm{I}^{\mathrm{b}}$ & $4.10 \pm 0.1^{c}$ & $3.60 \pm 0.1^{c}$ & $0.88^{\mathrm{b}}$ & $0.12^{\mathrm{c}}$ & $0.2(3 h)^{c}$ \\
\hline 8 & $0.740 \pm 0.0 \mathrm{I}^{\mathrm{a}}$ & $9.90 \pm 0.1^{b}$ & $8.80 \pm 0.1^{\mathrm{ab}}$ & $0.89^{\mathrm{ab}}$ & $0.29^{b}$ & $0.8(3 h)^{b}$ \\
\hline 8.5 & $0.760 \pm 0.0 \mathrm{I}^{\mathrm{a}}$ & $10.2 \pm 0.2^{\mathrm{ab}}$ & $9.0 \pm 0.1^{a}$ & $0.88^{\mathrm{b}}$ & $0.3^{\mathrm{a}}$ & $1.2(3 h)^{\mathrm{a}}$ \\
\hline 9 & $0.680 \pm 0.0 \mathrm{I}^{\mathrm{a}}$ & $\mid 1.5 \pm 0 . \mathrm{I}^{\mathrm{a}}$ & $10.4 \pm 0 . I^{a}$ & $0.90^{\mathrm{a}}$ & $0.35^{\mathrm{a}}$ & I.6 (3h) ${ }^{a}$ \\
\hline 10 & $0.532 \pm 0.0 \mathrm{I}^{\mathrm{b}}$ & $5.40 \pm 0.4^{c}$ & $4.20 \pm 0.1^{c}$ & $0.78^{c}$ & $0.14^{c}$ & $0.12(3 h)^{c}$ \\
\hline 11 & $0.187 \pm 0.0 \mathrm{I}^{\mathrm{d}}$ & $0.0 \pm 0.0^{d}$ & $0.0 \pm 0.0^{\mathrm{d}}$ & $0.00^{\mathrm{d}}$ & $0.00^{d}$ & $0.00^{\mathrm{d}}$ \\
\hline
\end{tabular}

'OD: maximum optical density, ${ }^{2}$ Maximum lactic acid concentration after $30 \mathrm{~h},{ }^{3}$ Lactic acid yield, ${ }^{4}$ Lactic acid productivity at the end of fermentation time, ${ }^{5}$ Maximum lactic acid productivity at indicated time. Different letters between columns denote that mean values are significantly different ( $\mathrm{p} \leq 0.05$ ) by Tukey LSD test, means $\pm S E(n=3)$.

Table 3 Effect of different concentrations of yeast extract, peptone and beef extract on the bacterial growth, glucose consumption, LA concentration, LA yield, LA productivity and maximum LA productivity from glucose by Psychrobacter maritimus BoMAir 5

\begin{tabular}{|c|c|c|c|c|c|c|c|}
\hline \multicolumn{2}{|c|}{ Nitrogen source (g/l) } & \multirow{2}{*}{$\begin{array}{l}\mathrm{OD}_{600} \mathbf{n m}^{\prime} \\
0.88 \pm 0.007^{\mathrm{b}}\end{array}$} & \multirow{2}{*}{$\begin{array}{l}\begin{array}{l}\text { Consumed } \\
\text { glucose }(\mathrm{g} / \mathrm{l})\end{array} \\
6.7 \pm 0.2^{\mathrm{c}}\end{array}$} & \multirow{2}{*}{$\begin{array}{l}\text { LA conc. } \\
(\mathrm{g} / \mathrm{I})^{2} \\
6.0 \pm 0.2^{\mathrm{c}}\end{array}$} & \multirow{2}{*}{$\begin{array}{l}\text { YLA }(\mathrm{g} / \mathrm{g})^{3} \\
0.90^{\mathrm{a}}\end{array}$} & \multirow{2}{*}{$\begin{array}{l}\text { PLA }(g / l / h)^{4} \\
0.20^{\mathrm{b}}\end{array}$} & \multirow{2}{*}{$\begin{array}{l}\text { Max.PLA } \\
(\mathrm{g} / \mathrm{l} / \mathrm{h})^{5}\end{array}$} \\
\hline \multirow{5}{*}{$\begin{array}{l}\text { Yeast extract } \\
\text { conc. (g/l) }\end{array}$} & 0 & & & & & & \\
\hline & 2.5 & $0.89 \pm 0.005^{\mathrm{ab}}$ & $7.6 \pm 0.3^{c}$ & $6.8 \pm 0.2^{c}$ & $0.89^{a}$ & $0.23^{b}$ & I.I $(3 h)^{b}$ \\
\hline & 5 & $0.9 \pm 0.003^{a}$ & $10.5 \pm 0.1^{\mathrm{a}}$ & $9.5 \pm 0.1^{\mathrm{ab}}$ & $0.89^{a}$ & $0.3 \mathrm{I}^{\mathrm{a}}$ & I.3(3h) $)^{\mathrm{ab}}$ \\
\hline & 7.5 & $0.92 \pm 0.003^{a}$ & $11.7 \pm 0.2^{\mathrm{a}}$ & $10.6 \pm 0.1^{\mathrm{a}}$ & $0.90^{\mathrm{a}}$ & $0.35^{a}$ & I.5(3h) ${ }^{\mathrm{a}}$ \\
\hline & 10 & $0.91 \pm 0.005^{\mathrm{a}}$ & $9.9 \pm 0.1^{b}$ & $9.0 \pm 0.1^{\mathrm{b}}$ & $0.91^{\mathrm{a}}$ & $0.30^{\mathrm{a}}$ & $1.0(3 \mathrm{~h})^{\mathrm{b}}$ \\
\hline \multirow{6}{*}{$\begin{array}{l}\text { Peptone conc. } \\
\text { (g/l) }\end{array}$} & 0 & $0.595 \pm 0.005^{d}$ & $6.2 \pm 0.1^{d}$ & $5.6 \pm 0.1^{d}$ & $0.90^{\mathrm{b}}$ & $0.19^{d}$ & $0.70(3 \mathrm{~h})^{\mathrm{d}}$ \\
\hline & 5 & $0.695 \pm 0.00 I^{c}$ & $7.4 \pm 0.3^{c}$ & $6.7 \pm 0.2^{c}$ & $\left.0.9\right|^{\mathrm{ab}}$ & $0.22^{c}$ & $0.80(3 h)^{c}$ \\
\hline & 10 & $0.857 \pm 0.010^{\mathrm{b}}$ & $\mid \mathrm{I} .5 \pm 0 . \mathrm{I}^{\mathrm{ab}}$ & $10.2 \pm 0.1^{a}$ & $0.90^{\mathrm{b}}$ & $0.27^{c}$ & $\mathrm{I} .0(3 \mathrm{~h})^{\mathrm{b}}$ \\
\hline & 15 & $0.872 \pm 0.004^{b}$ & $\mid \mathrm{l} .6 \pm 0 . \mathrm{I}^{\mathrm{ab}}$ & $10.3 \pm 0.2^{\mathrm{a}}$ & $0.92^{\mathrm{a}}$ & $0.3 I^{\mathrm{b}}$ & I.2(3h) ${ }^{\mathrm{b}}$ \\
\hline & 20 & $0.983 \pm 0.005^{\mathrm{a}}$ & $12.0 \pm 0.1^{\mathrm{a}}$ & $10.8 \pm 0.1^{\mathrm{a}}$ & $0.90^{\mathrm{b}}$ & $0.36^{a}$ & $1.6(3 \mathrm{~h})^{\mathrm{a}}$ \\
\hline & 25 & $0.834 \pm 0.005^{b}$ & $1 \mathrm{I} .0 \pm 0.1^{\mathrm{b}}$ & $9.8 \pm 0.1^{b}$ & $0.89^{c}$ & $0.33^{\mathrm{a}}$ & I.3 $(3 \mathrm{~h})^{\mathrm{ab}}$ \\
\hline
\end{tabular}




\begin{tabular}{|c|c|c|c|c|c|c|}
\hline Nitrogen source $(\mathrm{g} / \mathrm{l})$ & $O D_{600} \mathrm{~nm}^{\prime}$ & $\begin{array}{l}\text { Consumed } \\
\text { glucose }(\mathrm{g} / \mathrm{l})\end{array}$ & $\begin{array}{l}\text { LA conc. } \\
(\mathrm{g} / \mathrm{l})^{2}\end{array}$ & YLA $(g / g)^{3}$ & $\operatorname{PLA}(g / / / h)^{4}$ & $\begin{array}{l}\text { Max.PLA } \\
(\mathrm{g} / / / \mathrm{h})^{5}\end{array}$ \\
\hline \multirow{6}{*}{ Beef extract } & $0.752 \pm 0.002^{\mathrm{b}}$ & $5.5 \pm 0.1^{e}$ & $4.9 \pm 0.1^{\mathrm{e}}$ & $0.89^{b}$ & $0.16^{d}$ & $0.8^{c}$ \\
\hline & $0.761 \pm 0.002^{\mathrm{b}}$ & $8.1 \pm 0.4^{c}$ & $7.3 \pm 0.3^{c}$ & $0.90^{\mathrm{a}}$ & $0.24^{c}$ & $1.2^{\mathrm{b}}$ \\
\hline & $0.822 \pm 0.007^{a}$ & $12.2 \pm 0.1^{a}$ & $10.9 \pm 0 . I^{\mathrm{a}}$ & $0.89^{\mathrm{b}}$ & $0.36^{\mathrm{a}}$ & $1.6^{\mathrm{a}}$ \\
\hline & $0.803 \pm 0.005^{a}$ & $10.1 \pm 0.2^{b}$ & $9.1 \pm 0.2^{b}$ & $0.90^{\mathrm{a}}$ & $0.30^{\mathrm{b}}$ & $1.3^{\mathrm{ab}}$ \\
\hline & $0.81 \pm 0.002^{\mathrm{a}}$ & $8.5 \pm 0.1^{c}$ & $7.6 \pm 0.0^{c}$ & $0.89^{\mathrm{b}}$ & $0.25^{c}$ & $1.2^{\mathrm{b}}$ \\
\hline & $0.744 \pm 0.00 \mathrm{I}^{\mathrm{b}}$ & $6.5 \pm 0.1^{d}$ & $5.8 \pm 0.1^{d}$ & $0.89^{b}$ & $0.19^{\mathrm{d}}$ & $0.9^{c}$ \\
\hline
\end{tabular}

'OD: maximum optical density; ${ }^{2}$ Maximum lactic acid concentration after $30 \mathrm{~h},{ }^{3}$ Lactic acid yield, ${ }^{4}$ Lactic acid productivity at the end of fermentation time, ${ }_{5}^{5}$ Maximum lactic acid productivity at indicated time. Different letters between columns denote that mean values are significantly different $(p \leq 0.05)$ by Tukey LSD test, means \pm SE $(n=3)$.

100

NR 027225 Psychrobacter maritimus strain Pi2-20

KJ939462 Psychrobacter maritimus strain RB 50

Psychrobacter maritimus strain BollAir 5

EU434444 Psychrobacter maritimus strain a226

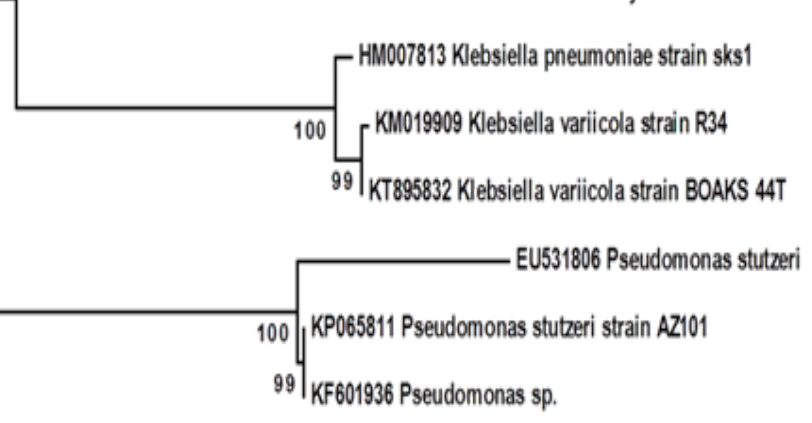

0.02

Figure I Phylogenetic analysis of I6S rRNA sequences of the bacterial isolate with the sequences from NCBI. Symbol $\square$ refers to I6S rRNA gene fragments retrieved from this study. The analysis was conducted with MEGA 6 using neighbor-joining method.

Higher concentrations of nitrogen sources led to decrease of all fermentation parameters indicating that these high concentrations might to be toxic as previously reported. ${ }^{26}$ In comparison with other reports, several researchers used YE as the sole organic nitrogen source. ${ }^{27-30}$ In order to substitute nitrogen sources in above optimized MRS media (7.5g/1 YE, 20g/1 peptone and $10 \mathrm{~g} / 1$ beef extract) with another inexpensive nutrient, seven nitrogen sources were used to evaluate their effects on LA production by Psychrobacter maritimus BoMAir 5. Unfortunately, none of these sources gave higher growth, sugar consumption, LA concentrations and LA productivity as obtained using organic sources in MRS media by selected strains in this study (Table 4). The importance of yeast extract, peptone and beef extract supplement could be explained by the fact that it contains critical amounts of vitamins and trace elements essential for LA biosynthesis. ${ }^{26}$ In the other studies, the peanut meal concentration of $20 \mathrm{~g} / 1$ was the most favourable for 1-LA production by Bacillus coagulans WCP10-4. ${ }^{7}$

\section{Effect of temperature}

Determination the optimal temperature degree for bacterial growth significantly affect the rate of biochemical reactions, generation time, bacterial enzymatic activity as well as conversion rate of different substrates. ${ }^{31}$ Table 5 summarized fermentation parameters for LA production by BoMAir 5 at different temperatures $\left(25-60^{\circ} \mathrm{C}\right)$ in batch fermentation mode. It was observed that $40^{\circ} \mathrm{C}$ represented the optimal temperature for LA fermentation parameters by BoMAir 5 where the maximum values of $\mathrm{OD}_{600}(0.86)$, glucose consumption $(12.3 \mathrm{~g} / \mathrm{l})$, LA concentration $(11.2 \mathrm{~g} / \mathrm{l})$ and LA productivity $(0.37 \mathrm{~g} / \mathrm{l} / \mathrm{h})$ were obtained (Table 5). However, increasing or decreasing in the temperature degree than that the optimal value, the microbial activity was substantially reduced due to most of bacterial enzymes were probably denatured. The final LA concentration was increased to $11.2 \mathrm{~g} / 1$ than that obtained in the previous experiment $(10.9 \mathrm{~g} / \mathrm{l})$. Surprisingly, this strain is thermotolerant; that preferred $40^{\circ} \mathrm{C}$ as an optimal fermentation temperature which is also an advantageous character to reduce the possibility of contamination risk. This thermotolerant characteristic is in contrary to Psychrobacter maritimus sp. nov that could grow only at $4-37^{\circ} \mathrm{C}$, with an optimal growth temperature of $25-28^{\circ} \mathrm{C}$ but does not grow at $39-40^{\circ} \mathrm{C} .{ }^{20}$

\section{Optimization of carbon source}

For industrial process, it is economically useful that the selected LA producing-bacteria have the ability to metabolize the different carbohydrates into optically pure LA through homo fermentative 
pathway without by-product formation. ${ }^{32}$ The presented study showed that, from the different carbon sources that can utilized by strain
BoMAir 5, glucose and fructose caused the highest LA production of $10.9 \mathrm{~g} / 1$ (Table 6), while the yield was higher in the case of glucose.

Table 4 Effect of different nitrogen sources on the bacterial growth, glucose consumption, LA concentration, LA yield, LA productivity and maximum LA productivity from glucose by Psychrobacter maritimus BoMAir 5

\begin{tabular}{|c|c|c|c|c|c|c|}
\hline Nitrogen source & $O D_{600 \mathrm{~nm}}{ }^{\prime}$ & $\begin{array}{l}\text { Consumed } \\
\text { glucose }(g / l)\end{array}$ & LA conc. $(g / I)^{2}$ & $\begin{array}{l}Y_{\text {LA }} \\
(g / g)^{3}\end{array}$ & $P_{\text {LA }}(g / l / h)^{4}$ & $\begin{array}{l}\operatorname{Max} . P_{\text {LA }} \\
(g / l / h)^{5}\end{array}$ \\
\hline Soybean & $0.630 \pm 0.003^{b}$ & $8.0 \pm 0.2^{b}$ & $7.4 \pm 0.1^{b}$ & $0.93^{\mathrm{a}}$ & $0.25^{b}$ & I.5 (3h) ${ }^{\mathrm{b}}$ \\
\hline Urea & $0.157 \pm 0.0 \mathrm{I}^{\mathrm{d}}$ & $2.6 \pm 0.1^{c}$ & $2.3 \pm 0.1^{c}$ & $0.88^{b}$ & $0.08^{c}$ & $0.5(3 h)^{c}$ \\
\hline Amm. Nitrate & $0.153 \pm 0.004^{c}$ & $2.4 \pm 0.0^{c}$ & $2.0 \pm 0.1^{d}$ & $0.83^{b}$ & $0.07^{c}$ & $0.6(3 h)^{c}$ \\
\hline Amm. Sulphate & $0.191 \pm 0.002^{c}$ & $2.4 \pm . .^{c}$ & $1.9 \pm 0.1^{d}$ & $0.79^{c}$ & $0.06^{c}$ & $0.6(3 h)^{c}$ \\
\hline Amm. Oxalate & $0.196 \pm 0.005^{c}$ & $2.7 \pm 0.0^{c}$ & $2.3 \pm 0.0^{c}$ & $0.85^{b}$ & $0.08^{c}$ & $0.6(3 h)^{c}$ \\
\hline Amm. Chloride & $0.177 \pm 0.004^{c}$ & $2.2 \pm 0.1^{\mathrm{d}}$ & $1.8 \pm 0.1^{\mathrm{d}}$ & $0.82^{b}$ & $0.06^{c}$ & $0.5(3 h)^{c}$ \\
\hline Amm ferric citrate & $0.110 \pm 0.01^{d}$ & $0^{e}$ & $0^{e}$ & $0^{d}$ & $0^{d}$ & $0^{d}$ \\
\hline Control & $0.994 \pm 0.0 \mathrm{I}^{\mathrm{a}}$ & $11.6 \pm 0.0^{\mathrm{a}}$ & $10.5 \pm 0.2^{\mathrm{a}}$ & $0.91^{a}$ & $0.35^{\mathrm{a}}$ & I.8 $(3 \mathrm{~h})^{\mathrm{a}}$ \\
\hline
\end{tabular}

'OD, maximum optical density; ${ }^{2}$ Maximum lactic acid concentration after $30 \mathrm{~h},{ }^{3}$ Lactic acid yield, ${ }^{4}$ Lactic acid productivity at the end of fermentation time, ${ }^{5}$ Maximum lactic acid productivity at indicated time. Different letters between columns denote that mean values are significantly different ( $p \leq 0.05$ ) by Tukey LSD test, means \pm SE $(n=3)$.

Table 5 Effect of different temperatures on the bacterial growth, glucose consumption, LA concentration, LA yield, LA productivity and maximum LA productivity by Psychrobacter maritimus BoMAir 5

\begin{tabular}{|c|c|c|c|c|c|c|}
\hline Temperature $\left({ }^{\circ} \mathrm{C}\right)$ & $O D_{600 \mathrm{~nm}}{ }^{\prime}$ & $\begin{array}{l}\text { Consumed } \\
\text { glucose (g/l) }\end{array}$ & $\begin{array}{l}\text { LA conc. } \\
(\mathrm{g} / \mathrm{l})^{2}\end{array}$ & $\mathbf{Y}_{\text {LA }}(g / g)^{3}$ & $P_{\text {LA }}(g / I / h)^{4}$ & $\begin{array}{l}\operatorname{Max} P_{\text {LA }} \\
(\mathrm{g} / \mathrm{l} / \mathrm{h})^{5}\end{array}$ \\
\hline 25 & $0.590 \pm 0.002^{c}$ & $7.10 \pm 0.1^{d}$ & $6.50 \pm 0.1^{d}$ & $0.92^{\mathrm{a}}$ & $0.22^{b}$ & $0.80(3 h)^{b}$ \\
\hline 30 & $0.630 \pm 0.005^{b}$ & $9.30 \pm 0.1$ & $8.40 \pm 0.1^{c}$ & $0.90^{\mathrm{a}}$ & $0.28^{b}$ & $1.0(3 \mathrm{~h})^{\mathrm{a}}$ \\
\hline 35 & $0.640 \pm 0.010^{\mathrm{b}}$ & $10.6 \pm 0.2^{b}$ & $9.60 \pm 0.1^{b}$ & $0.91^{\mathrm{a}}$ & $0.32^{\mathrm{a}}$ & $1.0(3 \mathrm{~h})^{\mathrm{a}}$ \\
\hline 40 & $0.860 \pm 0.004^{a}$ & $12.3 \pm 0 . I^{a}$ & $\mid \mathrm{I} .2 \pm 0 . \mathrm{I}^{\mathrm{a}}$ & $0.9 I^{\mathrm{a}}$ & $0.37^{\mathrm{a}}$ & I.3(3h) $)^{\mathrm{a}}$ \\
\hline 45 & $0.630 \pm 0.002^{\mathrm{b}}$ & $11.1 \pm 0.2^{\mathrm{a}}$ & $10.0 \pm 0.1^{a}$ & $0.90^{\mathrm{a}}$ & $0.33^{\mathrm{a}}$ & $1.0(3 \mathrm{~h})^{\mathrm{a}}$ \\
\hline 50 & $0.520 \pm 0.007^{d}$ & $9.00 \pm 0.1^{c}$ & $8.10 \pm 0.1^{c}$ & $0.90^{\mathrm{a}}$ & $0.27^{b}$ & $1.0(3 \mathrm{~h})^{\mathrm{a}}$ \\
\hline 55 & $0.430 \pm 0.07 e$ & $8.10 \pm 0.1^{c}$ & $7.30 \pm 0.1^{d}$ & $0.90^{\mathrm{a}}$ & $0.24^{b}$ & $0.90(3 \mathrm{~h})^{\mathrm{b}}$ \\
\hline 60 & $0.210 \pm 0.006^{f}$ & $0.00^{\mathrm{e}}$ & $0.00^{\mathrm{e}}$ & $0.0^{\mathrm{b}}$ & $0.00^{c}$ & $0.0^{c}$ \\
\hline
\end{tabular}

'OD, maximum optical density; ${ }^{2}$ Maximum lactic acid concentration after $30 \mathrm{~h},{ }^{3}$ Lactic acid yield, ${ }^{4}$ Lactic acid productivity at the end of fermentation time, ${ }^{5}$ Maximum lactic acid productivity at indicated time. Different letters between columns denote that mean values are significantly different ( $\leq \leq 0.05$ ) by Tukey LSD test, means \pm SE $(n=3)$.

Table 6 Lactic acid production using different carbon sources by Psychrobacter maritimus BoMAir 5

\begin{tabular}{|c|c|c|c|c|c|c|}
\hline Carbon source & $O D_{600 \mathrm{~nm}}{ }^{\prime}$ & $\begin{array}{l}\text { Consumed } \\
\operatorname{sugar}(g / l)\end{array}$ & LA conc. $(g / l)^{2}$ & $Y_{\text {LA }}(g / g)^{3}$ & $P_{\text {LA }}(g / l / h)^{4}$ & $\begin{array}{l}\operatorname{Max} P_{\text {LA }} \\
(\mathrm{g} / \mathrm{l} / \mathrm{h})^{5}\end{array}$ \\
\hline Glucose & $0.723 \pm 0.006^{\mathrm{a}}$ & $12.0 \pm 0 . I^{a}$ & $10.9 \pm 0.1^{\mathrm{a}}$ & $0.9 \mathrm{I}^{\mathrm{a}}$ & $0.36^{a}$ & I.3 $(3 \mathrm{~h})^{\mathrm{a}}$ \\
\hline Fructose & $0.76 \pm 0.01 \mathrm{I}^{\mathrm{a}}$ & $12.6 \pm 0.1^{\mathrm{a}}$ & $10.9 \pm 0.1^{\mathrm{a}}$ & $0.86^{a}$ & $0.36^{\mathrm{a}}$ & I.I $(3 h)^{a}$ \\
\hline Lactose & $0.545 \pm 0.013^{c}$ & $0.0 \pm 0.0^{c}$ & $0.0 \pm 0.0^{c}$ & $0.0^{\mathrm{b}}$ & $0.0^{\mathrm{b}}$ & $0.0^{\mathrm{b}}$ \\
\hline Sucrose & $0.495 \pm 0.007^{d}$ & $0.0 \pm 0.0^{c}$ & $0.0 \pm 0.0^{c}$ & $0.0^{c}$ & $0.0^{c}$ & $0.0^{\mathrm{b}}$ \\
\hline Raffinose & $0.437 \pm 0.003^{d}$ & $0.0 \pm 0.0^{c}$ & $0.0 \pm 0.0^{c}$ & $0.0^{\mathrm{d}}$ & $0.0^{c}$ & $0.0^{c}$ \\
\hline Maltose & $0.695 \pm 0.003^{b}$ & $2.3 \pm 0.0^{b}$ & $1.9 \pm 0.1^{\mathrm{b}}$ & $0.83^{b}$ & $0.06^{\mathrm{b}}$ & $0.19(3 \mathrm{~h})^{\mathrm{b}}$ \\
\hline Starch & $0.489 \pm 0.009^{d}$ & $0 \pm 0.0^{c}$ & $0.0 \pm 0.0^{c}$ & $0.0^{\mathrm{d}}$ & $0.0^{c}$ & $0.0^{c}$ \\
\hline Cellulose & $0.504 \pm 0.008^{c}$ & $0 \pm 0.0^{c}$ & $0.0 \pm 0.0^{c}$ & $0.0^{\mathrm{d}}$ & $0.0^{c}$ & $0.0^{c}$ \\
\hline
\end{tabular}

'OD, maximum optical density; ${ }^{2}$ Maximum lactic acid concentration after $30 \mathrm{~h},{ }^{3}$ Lactic acid yield, ${ }^{4}$ Lactic acid productivity at the end of fermentation time, 5 Maximum lactic acid productivity at indicated time. Different letters between columns denote that mean values are significantly different ( $\mathrm{p} \leq 0.05$ ) by Tukey LSD test, means \pm SE $(n=3)$. 


\section{Effect of different glucose concentration}

The high initial substrate tolerance is very important for getting high LA production to reduce the downstream processing costs. ${ }^{33}$ In batch fermentation, BoMAir 5 strain exhibited the growth increase with the increase of glucose concentrations up to $60 \mathrm{~g} / 1$ recording the maximal OD 3.93, while the growth decreased after that. The results represent in Figure 2 indicated substrate inhibition that resulted in long lag phase at higher concentrations above $60 \mathrm{~g} / 1$ followed by short log phase and very long stationary phase. Final LA concentration was increased

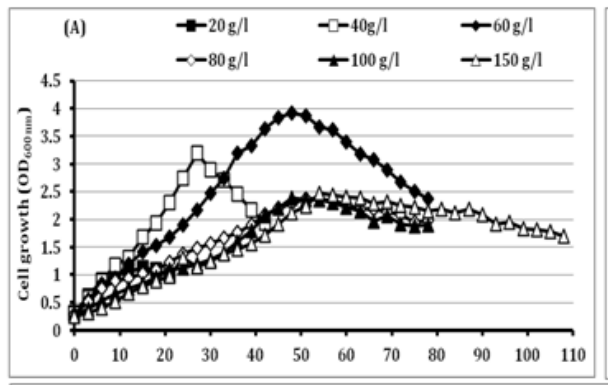

(C)

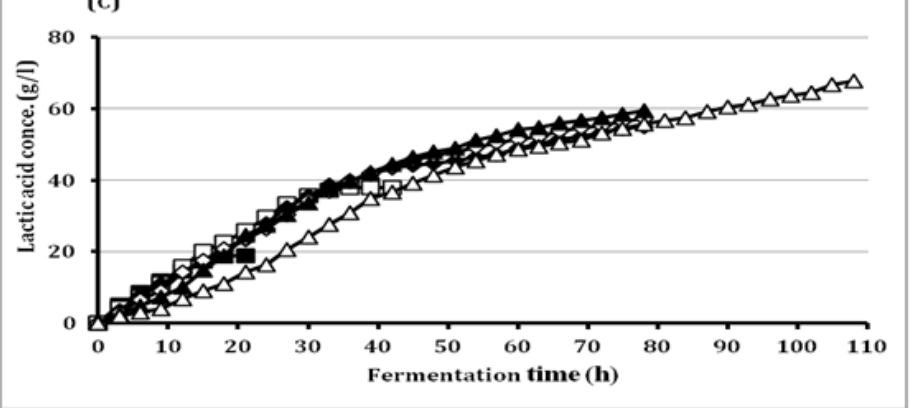

from $18.9 \mathrm{~g} / 1$ up to $67.9 \mathrm{~g} / 1$ using initial glucose concentrations of $20 \mathrm{~g} / 1$ and $150 \mathrm{~g} / \mathrm{l}$, respectively. Therefore, the residual glucose concentration was very high $(80 \mathrm{~g} / \mathrm{l})$ when using $150 \mathrm{~g} / 1$ glucose. Surprisingly, BoMAir 5 strain metabolizes glucose homo fermentatively strain at all tested concentrations, where yielding LA range of $0.95-0.97 \mathrm{~g} / \mathrm{g}$ of glucose consumed. On the other hand, LA productivity was increased with the increase of initial glucose concentration up to $40 \mathrm{~g} / \mathrm{l}$ while become decreased vigorously when the initial glucose concentration was higher than $40 \mathrm{~g} / \mathrm{l}$. Therefore, the $40 \mathrm{~g} / \mathrm{l}$ glucose was selected as the optimal concentration for further studies.

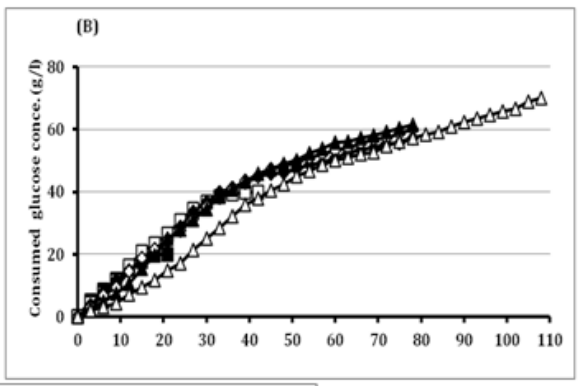

Figure 2 Effect of different glucose concentrations on

(A) Cell growth

(B) Glucose consumption and

(c) Lactic acid production by BoMAir 5 at $40^{\circ} \mathrm{C}$.

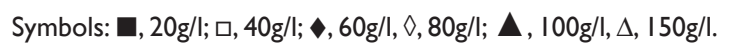

\section{Fed batch fermentation}

The batch culture in most cases produces lower LA concentration, biomass and productivity than other fermentation modes. This could have resulted from the high osmotic pressure on microbial cells in the batch culture condition and the reduced water activity combined with plasmolysis caused by high substrate concentration that results in a decrease in the fermentation rate and sugar consumption. ${ }^{26}$ The current study assumed that, using low initial glucose concentration at the beginning of fermentation and feeding with sugars during fermentation, the effects of glucose inhibition on LA production would be avoided and the fermentation efficiency would be greatly enhanced. Therefore, we conducted fed batch fermentations with multi-pulse feeding under $\mathrm{pH}$ control at $\mathrm{pH} 9.0$ using $10 \mathrm{M} \mathrm{NaOH}$ as a neutralizing agent. The initial glucose concentration was $40 \mathrm{~g} / \mathrm{l}$ and the multi-pulse (four) feedings were achieved by $30 \mathrm{~g} / 1$ of glucose and $1 \mathrm{~g} / \mathrm{l}$ of YE when the glucose concentration reached to 10.0g/l (Figure 3).

The growth of BoMAir 5 strain was increased with time up to 81 $\mathrm{h}$ where they obtained $\mathrm{OD}_{600}$ was 16.3 and become stable for another $27 \mathrm{~h}$ then decreased gradually until fermentation was ended recording $\mathrm{OD}_{600}$ of 10.44 at $306 \mathrm{~h}$. Final LA concentration was improved with
$107.3 \%$ than at batch fermentation where $140.8 \mathrm{~g} / 1$ LA with low residual glucose concentration of $9.48 \mathrm{~g} / 1$ were achieved with fed batch fermentation than in case of batch method where only $67.9 \mathrm{~g} / \mathrm{l}$ of LA with very high residual glucose of $80 \mathrm{~g} / \mathrm{L}$ using $160 \mathrm{~g} / 1$ and $150 \mathrm{~g} / \mathrm{L}$ glucose, respectively. Interestingly, LA yield at all fermentation time were ranged $0.93-0.99 \mathrm{~g} / \mathrm{g}$ of glucose consumed indicating that, BoMAir 5 strain metabolized glucose homo fermentatively where only $2.6 \mathrm{~g} / \mathrm{l}$ acetic acid was detected at the end of fermentation. On the other hand, LA productivity gave the highest value at the early stage of fermentation while decreased at other stages as a result of accumulation of LA concentration causing end product inhibition. Except for an alkalophilic Bacillus sp. WL-S20 that produced $225 \mathrm{~g} / 1$ from glucose at a yield of $99.3 \mathrm{~g} / \mathrm{g}$ using multi-pulse fed batch fermentation, ${ }^{7}$ the final LA concentration $(140.8 \mathrm{~g} / \mathrm{l})$ and LA yield $(0.93-0.99 \mathrm{~g} / \mathrm{g}$ of glucose consumed) obtained in the current study under alkaliphilic condition using the green neutralizer $(\mathrm{NaOH})$ to maintain the $\mathrm{pH}$ during fermentation were acceptable when compared with other wildtype alkaliphilic strains e.g Halolactibacillus halophilus (65.8g/1 1-LA with yield of $0.76 \mathrm{~g} / \mathrm{g}){ }^{10}$ Exiguobacterium $8-11-1(125 \mathrm{~g} / 1$ of L-LA with a yield of $0.98 \mathrm{~g} / \mathrm{g}),{ }^{12}$ Enterococcus casseliflavus $79 \mathrm{w} 3(103 \mathrm{~g} / \mathrm{l}$ of L-LA with yield of $0.80 \mathrm{~g} / \mathrm{g}){ }^{13}$ 


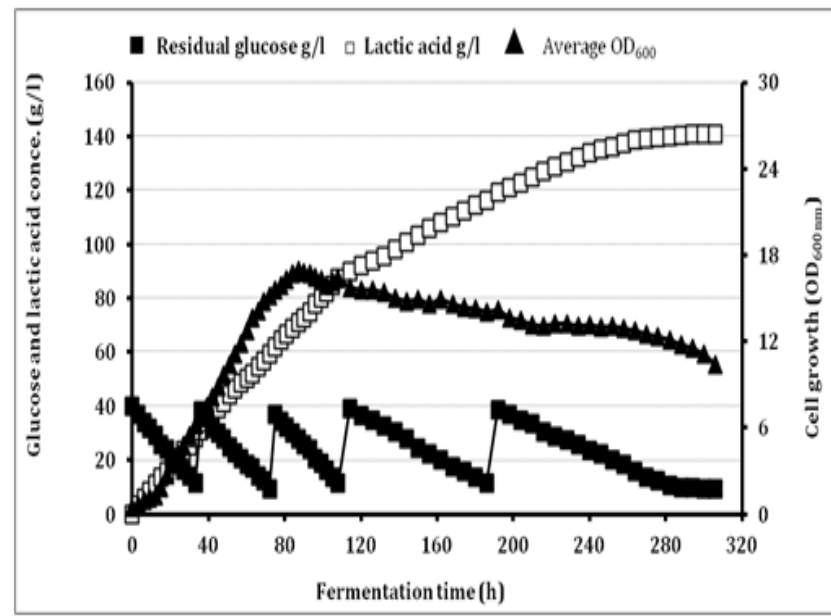

Figure 3 Lactic acid production in fed batch fermentation by BoMAir 5 using initial glucose concentration of $40 \mathrm{~g} / \mathrm{l}$ at $40^{\circ} \mathrm{C}$. Symbols: $\mathbf{r e s i d u a l}$ glucose; $\square$ average LA, $\mathbf{\Delta}$ Average optical density.

\section{Conclusion}

In this novel alkaliphilic bacterial strain of BoMAir 5 was isolated and identified as Psychrobacter maritimus BoMAir 5. This strain showed the highest capacity to produce LA under alkaline conditions using different glucose concentrations. Fermentation conditions were optimized in batch fermentations, where efficient production of polymer-grade lactate by alkaliphilic bacterial strain of BoMAir 5 was established using fed batch fermentation technique. Psychrobacter maritimus BoMAir 5 has merits of high $\mathrm{pH}$ adaptation (9.0), high yield of glucose to LA $(0.93-0.99 \mathrm{~g} / \mathrm{g}$ of glucose consumed) and high LA production titre (140.8g/l). Alkaliphilic characteristic of BoMAir 5 strain can be useful to reduce the risk of contamination during fermentation technique. Considering the above performance, Psychrobacter maritimus BoMAir 5 appears to be suitable for industrial scale production of lactic acid.

\section{Acknowledgements}

None.

\section{Conflict of interest}

The author declares no conflict of interest.

\section{References}

1. Pang X, Zhuang X, Tang Z, et al. Polylactic acid (PLA): research, development and industrialization. Biotechnol J. 2010;5(11):1125-1136.

2. Wang L, Zhao B, Liu B, et al. Efficient production of 1-lactic acid from corncob molasses, a waste by-product in xylitol production, by a newly isolated xylose utilizing Bacillus sp. strain. Bioresour Technol. 2010;101(20):7908-7915.

3. Zhao B, Wang L, Ma C, et al. Repeated open fermentative production of optically pure 1-lactic acid using a thermophilic Bacillus sp. Strain. Bioresour Technol. 2010;101(16):6494-6498.

4. Richter K, Berthold C. Biotechnological conversion of sugar and starchy crops into lactic acid. Journal of Agricultural Engineering Research. 1998;71(2):181-191.

5. Abdel-Rahman MA, Tashiro Y, Zendo T, et al. Highly efficient L-lactic acid production from xylose in cell recycle continuous fermentation using Enterococcus mundtii QU 25. RSC Adv. 2016;6:17659-17668.
6. Litchfield JH. Microbiological production of lactic acid. Adv Appl Microbiol. 1996;42:45-95.

7. Meng Y, Xue Y, Yu B, et al. Efficient production of 1- lactic acid with high optical purity by alkaliphilic Bacillus sp. WL-S20. Bioresour Technol. 2012;116:334-339.

8. Abdel-Rahman MA, Sonomoto K. Opportunities to overcome the current limitations and challenges for efficient microbial production of optically pure lactic acid. J Biotechnol. 2016;236:176-192.

9. Horikoshi K. Alkaliphiles: some applications of their products for biotechnology. Microbiol. Microbiol Mol Biol Rev. 1999;63(4):735-750.

10. Calabia BP, Tokiwa Y, Aiba S. Fermentative production of 1- (+)-lactic acid by an alkaliphilic marine microorganism. Biotechnol Lett. 2011;33(7):1429-1433.

11. Paavilainen S, Helistö P, Korpela T. Conversion of carbohydrates to organic acids by alkaliphilic bacilli. Journal of Fermentation and Bioengineering. 1994;78(3):217-222.

12. Jiang X, Xue Y, Wang A, et al. Efficient production of polymer-grade 1-lactate by an alkaliphilic Exiguobacterium sp. strain under nonsterile open fermentation conditions. Bioresource Technology. 2013;143:665668.

13. Yokaryo H, Tokiwa Y. Isolation of alkaliphilic bacteria for production of high optically pure 1-(+)-lactic acid. J Gen Appl Microbiol. 2014;160(6):270-275.

14. Assavasirijinda N, Ge D, Yu B, et al. Efficient fermentative production of polymer-grade D-lactate by an engineered alkaliphilic Bacillus $s p$. strain under non-sterile conditions. Microb Cell Fact. 2016;15:3.

15. Manual of Microbiological Methods. Committee on Bacteriological Technic. American Society for Microbiology. New York, USA: McGraw-Hill; 1957. 338 p.

16. Halebian S, Harris B, Finegold SM, et al. Rapid method that aid in distinguishing Gram-positive from Gram-negative anaerobic bacteria. $J$ Clin Microbiol. 1981;13(3):444-448.

17. Miller GL. Use of dinitrosalicylic acid reagent for determination of reducing sugar. Analytical Chemistry. 1959;31(3):426-428.

18. Lane DJ. $16 \mathrm{~S} / 23 \mathrm{~S}$ rRNA sequencing. In: Stackebrandt E, et al. editors. Nucleic acid techniques in bacterial systematics. Chichester, UK: John Wiley and Sons; 1991. p. 115-175.

19. Barker SB, Summerson WH. The colorimetric determination of lactic acid in biological material. J Biol Chem. 1941;138:535-554.

20. Romanenko LA, Lysenko AM, Rohde M, et al. Psychrobacter maritimus sp. nov and Psychrobacter arenosus sp. nov., isolated from coastal sea ice and sediments of the Sea of Japan. Int J Syst Evol Microbiol. 2004;54(Pt 5):1741-1745.

21. Yumoto I, Narisawa MH, Hirota K, et al. Exiguobacterium oxidotolerans sp. nov., a novel alkaliphile exhibiting high catalase activity. Int $J$ Syst Evol Microbiol. 2004;54(Pt 6):2013-2017.

22. Yadav AK, Chaudhari AB, Kothari RM. Bioconversion of renewable resources into lactic acid: an industrial view. Crit Rev Biotechnol. 2011;31(1):1-19.

23. Åkerberg C, Hofvendahl $\mathrm{K}$, Zacchi G, et al. Modelling the influence of $\mathrm{pH}$, temperature, glucose and lactic acid concentrations on the kinetics of lactic acid production by Lactococcus lactis ssp. lactis ATCC 19435 in whole-wheat flour. Appl Microbiol Biotechnol. 1998;49(6):682-690.

24. Ding S, Tianwei Tan. 1-Lactic acid production by Lactobacillus casei fermentation using different fed-batch feeding strategies. Process Biochemistry. 2006;41(6):1451-1454. 
25. Oh H, Wee YJ, Yun JS, et al. Lactic acid production through cell-recycle repeated-batch bioreactor. Appl Biochem Biotechnol. 2003;105(108):603-613.

26. Kotzamanidis CH, Roukas T, Skaracis G. Optimization of lactic acid production from beet molasses by Lactobacillus delbrueckii NCIMB 8130. World Journal of Microbiology. 2002;18(5):441-448.

27. Aeschlimann A, Von Stockar U. The effect of yeast extract supplementation on the production of lactic acid from whey permeate by Lactobacillus helveticus. Appl Microbiol Biotechnol. 1990;32(4):398-402.

28. Chiarini L, Mara L, Tabacchioni S. Influence of growth supplements on lactic acid production in whey ultra-filtrate by Lactobacillus helveticus. Appl Microbiol Biotechnol. 1992;36(4):461-464.

29. Göksungur Y, Güvenç U. Continuous production of lactic acid from beet molasses by L. delbrueckii IFO 3202. J. Chem. Technol. Biotechnol. 1997;69(4):399-404.
30. Dumbrepatil A, Adsul M, Chaudhari S, et al. Utilization of molasses sugar for lactic acid production by Lactobacillus delbrueckii subsp. delbrueckii mutant Uc-3 in batch fermentation. Appl Environ Microbiol. 2008;74(1):333-335.

31. Jung YK, Lee SY. Efficient production of polylactic acid and its copolymers by metabolically engineered Escherichia coli. J Biotechnol. 2011;151(1):94-101.

32. Abdel-Rahman MA, Tashiro Y, Sonomoto K. Recent advances in lactic acid production by microbial fermentation processes. Biotechnology Advances. 2013;31(6):877-902.

33. Zhou X, Ye L, Wu JC. Efficient production of 1-lactic acid by newly isolated thermophilic Bacillus coagulans WCP10-4 with high glucose tolerance. Appl Microbiol Biotechnol. 2013;97(10):4309-4314. 